\title{
Türkiye'de İthalatın Artmasında Lüks Malların Rolü: Akıllı Cep Telefonu Talebi
}

\section{Hakan TUNÇ}

${ }^{1}$ Asst. Prof. Dr., Burdur Mehmet Akif Ersoy University, Faculty of Economics and Administrative Sciences, Department of Banking and Finance, Burdur, Turkey

Geliş Tarihi/Received: 17.09.2019

Kabul Tarihi/Accepted: 05.03.2020
Doi: doi.org/10.31200/makuubd.621299

Araştırma Makalesi/Research Article

\section{ÖZET}

Günümüz yaşam koşullarında, bilişim sektörünün desteği ile gelişen akıllı cep telefonları sağladığ1 faydalar itibariyle zorunlu mal haline gelmiştir. Akıllı cep telefonları, bilgisayar teknolojilerinin de desteğiyle adeta bir cep bilgisayarı haline dönüşmüş, bu dönüşüm sayesinde kişiler internet kullanımlarını kişisel bilgisayarları yerine akı1lı telefonları aracılığıyla gerçekleştirmektedir. Bu dönüşüme ek olarak firmalar arasında artan rekabet koşulları daha kaliteli cep telefonu üretimini artırırken, cep telefonlarının fiyatı da artırmış ve bazı akıllı cep telefonları lüks mal haline gelmiştir. Ayrıca kendi cep telefonunu üretemeyen ülkeler açısından da ithalatta ciddi artışa neden olmaktadır. 2018 yılında yaklaşık 2 milyar dolar akıllı cep telefonu ithalatı gerçekleşmiştir.

Bu çalışmada kişilerin Iphone 7 marka cep telefonuna olan talebi, İstanbul bölgesinde rastgele örneklem yöntemiyle 258 kişiye yapılan anket yardımıyla incelenmeye çalışılmıştır. Çalışma da çok değişkenli regresyon modeli ve Anova testi yardımıyla kişilerin Iphone 7 marka cep telefonuna olan talebinde kişilerin yaş aralığı ve babalarının eğitim seviyesi etkili olduğu ayrıca Iphone fiyatlarını takip etmedeki artış, internette markalı bazı ürünlerin ucuz olduğunu düşüncesindeki artış ve fiyat biraz yüksek olsa dahi daha uzun süre kullanma niyetiyle markalı cep telefonu kullanma eğilimindeki artışın Iphone 7 marka cep telefonuna olan talebi artırdığı tespit edilmiştir.

Anahtar kelimeler: Cep Telefonu, Regresyon, Iphone 7, Lüks Mal, İthalat. 
Tunç, H.

\title{
Role of Luxury Goods Increase in Imports in Turkey: Smart Mobile Phone Demand
}

\begin{abstract}
In today's living conditions, improvement smart mobile phones with the support of the IT sector has become necessary good for the benefits it provides. With the support of computer technology, smart mobile phones have become a mobile computer, because of this conversion, people use internet instead of personal computers through smartphones. In addition to this transformation, while increasing competition among companies has increased the production of higher quality mobile phones, the price of mobile phones has also increased and some smart phones have become luxury goods. It also causes a serious increase in imports for countries that cannot produce their own mobile phones. In 2018, nearly 2 billion dollars of smart mobile phones were imported in Turkey.

In this study, the demand for the Iphone 7 smart mobile phone was tried to be examined with the help of a questionnaire made to 258 people by random sampling method in İstanbul region. In the study, a multivariable regression model was established, people demand for Iphone 7 smart mobile phone when the the age range of the persons and the level of education of their father was effective, The increase in Iphone prices, an increase in the belief that some products branded on the internet are cheap, and the increase in the tendency to use a branded mobile phone with the intention of using it for a longer period even if the price is a little high, has increased the demand for Iphone 7 brand mobile phone.
\end{abstract}

Keywords: Mobile Phone, Regression, Iphone 7, Luxury Goods, Import.

\section{GÍRİŞ}

Keynesyen ekonominin doğumu ile birlikte arz yönlü ekonomiler yerini talep yönlü ekonomilere bırakmıştır. Keynes bir ekonomide itici gücün efektif talep olduğunu kişilerin tüketim eğilimlerindeki artışın ekonomilerin büyümesinin nedeni olduğunu savunmuştur. Kişilerin tasarruf eğilimlerini artırması durumunda Keynes devletler adına hükümetlerin devreye girmesi gerektiğini ve harcama yaparak ekonomide toplam talebi artırması gerektiğini ifade etmiştir. Toplam talepteki bu artış daha sonra üretilen reel mal ve hizmetlerde bir artışa da neden olacaktır.

Gelişmekte olan ülkelerde son yıllarda yaşanan önemli ekonomik sorunların başında cari açık sorunu gelmektedir. Özellikle enerji ithalatı ile başlayan daha sonra lüks malların 
ithalatı ile devam eden süreçte karar vericiler sürekli kur riski ile karşılaşmaktadır. Sürekli büyüme eğiliminde olan gelişmekte olan ülkeler yerli üretimin gelişememesi durumunda diş talep ile karşılamaktadır.

Kişilerin talebini etkileyen en önemli değişkenin fiyat olduğunu ifade eden talep kanunu, her malın fiyatındaki değişimin talepte aynı etkiyi yaratmayacağını da vurgulamış ve malın türüne göre farklılaşan bir fiyat- talep ilişkisinden bahsetmiştir. Bu ilişki, bir malın fiyatındaki yüzde değişmelere karşın talep edilen miktarındaki yüzde değişmeleri ölçen talep esnekliği yardımıyla farklılaşmaktadır. Ayrıca kişilerin mallara olan talebi malın fiyatına olduğu kadar kişinin gelirine de duyarlıdır. Kişinin gelirindeki yüzde değişmelere karşın talep edilen miktarındaki yüzde değişmelere gelir esnekliği şeklinde ifade edilmektedir (Türkay, 1986).

Tüketim sonucunda kişinin gelirinden büyük pay alan mallara lüks mal denmektedir. Kişilerin geliri arttıkça lüks mallara olan talep artmaktadır (Ünsal, 1998: 76). Lüks malların en önemli özelliği, talep esnekliğinin ve gelir esnekliğinin birden büyük olmasıdır. İktisat biliminde gelir ile satın alınan mallar arasındaki ilişki Engel Eğrileri yardımıyla analiz edilmektedir. Lüks mallara ilişkin Engel Eğrisi şekil 1'de verilmiştir.

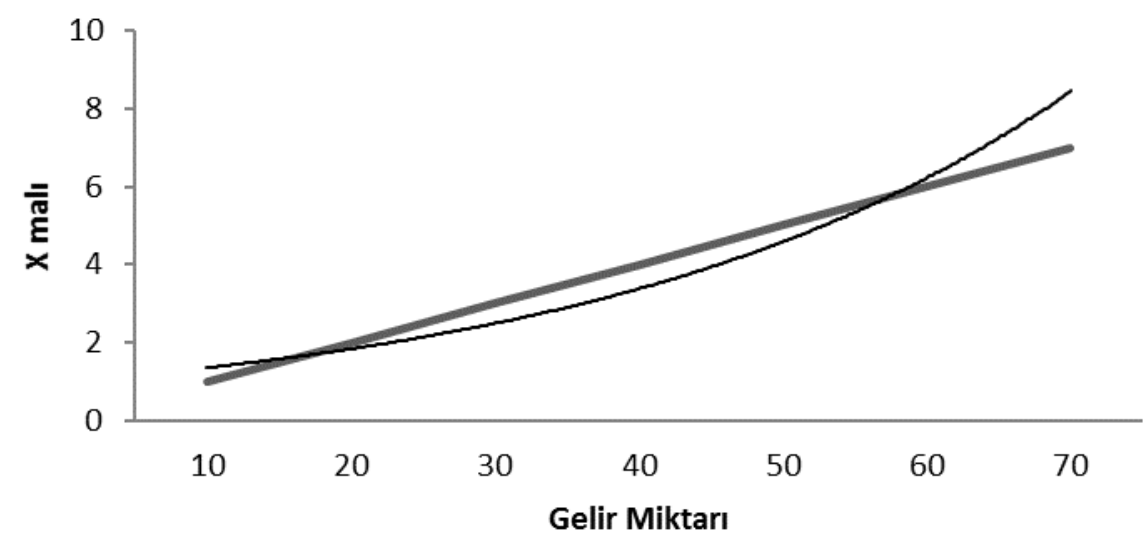

Şekil 1. Lüks mallarda Engel Eğrisi

Şekil 1 incelendiğinde y ekseni geliri x ekseni ise talep edilen miktarı göstermektedir. Grafiğin pozitif yönlü olması kişinin gelirindeki artışın lüks mallarda talebi artırdığını göstermektedir.

Engel eğrileri ile teklif eğrileri birbirinden farklı yaklaşımlardır. Teklif eğrileri iki mallı model olup iki malında fiyatı sabit olması durumunda gelir artışından nasıl etkilendiğini gösterirken, Engel eğrilerinde tek bir malın fiyatının sabit kalması sonucu gelir artışından nasıl 
etkilendiğini göstermektedir (Varian,2010: 98). Engel eğrisi gelir değiş̧ikliğine karşın malın talebindeki değişikli gösterdiği için engel eğrilerine gelir-talep eğrisi adı da verilmektedir (Türkay, 1986: 28). Lüks malların talebinde etkili olan faktörlerden bir diğeri de geleceğe ilişkin beklentilerdir. Çoğu zaman kişiler gelecekte fiyatını düşeceğini bildiği malları bugün tüketmemeyi tercih etmektedir. İktisat biliminde çok fazla beklenti teorisi mevcuttur. $\mathrm{Bu}$ teoriler kişilerin beklentilerinin kaynağı ve bu beklenti sonucunda oluşan davranış çeşitliliği açısından farklılaşmaktadır.

Rasyonel olan bireylerin talep etmeden önce ilgili mala ilişkin her türlü bilgiyi daha önce toplayıp kendine bir beklenti yaratma sürecine rasyonel bekleyişler hipotezi olarak ifade edilmektedir (Sargent ve Vallace, 1976: 169-183). Özellikle ekonomi politikasının etkinliği açısından bireylerin politikayı önceden tahmin etmesinin rolü rasyonel bekleyişler hipotezinin temel çalışma alanıdır. Bilgi ve iletişim ağlarının gelişimi kişilerin firmaların fiyat politikalarına ilişkin önceden başarılı tahminler yapabilme yeteneğini artırmada ve bu durum talebi de etkilemektedir.

Lüks malların talebini etkileyen önemli bir faktörde kişilerin zevk ve tercihlerdir. Kişiler tüketirken kendi zevk ve tercihlerinin yanında başkalarının zevk ve tercihlerinden de etkilenebilmektedir (Şahin, 2005: 192). Özellikle çalışmanın konusu kapsamında olan Akıllı telefon sektöründe birbirine benzer özelliğe sahip çok fazla ürün olması ve fiyatların birbirine çok yakın olması talepte zevk ve tercihleri ön plana çıkarabilmektedir.

Bu çalışmada bir kısmı lüks kabul edilen cep telefonları arasında son yıllarda Türkiye’de yaygın olarak kullanılan İphone marka telefonların talebinde etkili olan bazı faktörler bir anket yardımıyla incelenmeye çalışılmıştır.

\section{AKILLI TELEFON TÜKETIMI}

Günümüzde akıllı cep telefonları navigasyon, fotoğraf makinası, kamera, not defteri gibi klasik özelliklerinin yanında kişileri sağlık kayıtlarını tutan akıllı sağlık asistan olma özelliğine sahiptir.

Akıllı cep telefonlarının gelişimi fiyatları üzerinde de baskı yaratmış, özelliklerine göre değişmekle birlikte bazıları lüks mal statüsüne sahip olmuştur. Kişilerin cep telefonu talebinde fiyat ve gelir dışında etki eden faktörlere ilişkin literatür de çok fazla çalışma mevcuttur. Türkiye'de yapılan araştırmaların büyük kısmı üniversite öğrencileri üzerinde yapılmıştır. Bunun nedeni üniversite öğrencilerinin akıllı cep telefonlarının sağladığı birçok faydayı 
optimum bir biçimde kullanabilmeleri sebebiyle cep telefonu talebinde karar verici konumuna gelmeleridir. Yapılan çalışmalarda üniversite öğrencilerinin cep telefonlarının bozulmasına ya da eskimesine ihtiyaç duymaksızın öğrencilerin yaklaşık yarısının 3-4 yılda bir öğrencilerin üçte birinin 2 yıl dolmadan cep telefonunu değiştirdikleri saptanmıştır (Karaslan ve Budak, 2012: 4567). 21-23 yaş aralığındaki öğrencilerin cep telefonuna 27 yaş aralığındaki kişilere göre daha çok anlam yüklediği ve 21-23 yaş aralığının Türkiye'de üniversite öğrencilerinin yaş aralığı frekansının en yoğun olduğu aralık olduğu bilinmektedir (Kuyucu, 2017: 328).

Üniversite öğrencilerinin Iphone marka cep telefonu kullanımlarına ilişkin yapılan bir çalışmada Iphone kullanıcılarının bu marka akıllı telefona karşı yüksek oranda statü tüketimi eğilimine sahip oldukları belirlenmiştir (Gökaliler vd., 2011: 46). Ayrıca Iphone marka cep telefonu kullananlarında operatör olarak Türkiye'nin ilk ve en geniş çekim ağına sahip olan operatörü Turkcell'i tercih ettikleri saptanmıştır (Tüzüntürk, 2017: 257). Bu durum üniversite öğrencilerinin sahip oldukları akıllı cep telefonlarını etkin bir biçimde kullanma eğilimlerini göstermektedir.

Üniversite öğrencileri üzerine yapılan başka bir çalışmada lüks cep telefonu tüketiminin israf olduğuna dair kanaatin varlığı ve öğrencilerin GPRS, MMS ve GPS (Navigasyon) özelliklerini ise neredeyse hiç kullanmadıkları saptanmıştır (Uzgören vd. 2013: 29). Ayrıca öğrencilerin cep telefonu marka tercihlerinde arkadaşlarından etkilendikleri ve öğrencilerin sahip olduğu cep telefonlarının anne ya da babası tarafında satın alındığına dair tespitler mevcuttur (Gülmez, 2005: 59). Öğrencilerin acil bir durumda ve tehlike zamanında yardım istemek ya da polise herhangi bir şüpheli durumu bildirmek amacıyla akıllı cep telefonları kullandıkları (Özaşçılar, 2012: 43) ve yapılan birçok çalışmada öğrencilerin gelirlerinin cep telefonu talebinde etkili olduğu sonucuna ulaşılmıştır (Yaşa ve Bozyiğit, 2012: 29).

Üniversite öğrencilerinin cep telefonu talebine ilişkin yurtdışında yapılan çalışmalarda üniversite öğrencilerinin cep telefonu kullanmalarında temel amaçlarının akademik bilgilere ulaşmak olduğunu tespit edilmiştir (Bomhold, 2013: 424). Kişilerin akıllı cep telefonu kullanımındaki artışa rağmen mobil pazarlama iletişimleri konusundaki olumsuz tutumlarının devam ettiği (Watson vd., 2013: 840) ve sosyal ihtiyaçların ve sosyal etkilerin öğrencilerin akıllı telefonlara bağımlılığını önemli ölçüde etkilediğini ortaya koyulmuştur. Ayrıca yapılan çalışmalarda akıllı telefonlara bağımlılık ile öğrencilerin satın alma davranışları arasında da güçlü bir ilişkinin varlığı (Suki, 2013: 124) ve cep telefonu bağımlılığını, dikkat dürtüsünün 
merkezi özelliğinin artırdığı çok net bir biçimde ortaya konulmuştur (Roberts vd., 2015: 13). Yapılan çalışmalarda kullanıcıların cinsiyeti, yaşı, mesleği ve gelirinin, sesli ve 3G İnternetli sözleşme ve aylık 3G İnternet ücretinin cep telefonu talebinde önemli etkileri olduğu (Hsiao ve Chen, 2015: 158) ve akıllı telefon kullanımının yakın ya da uzak arkadaşlarla iletişimi kolaylaştırdığı için tercih edildiği ifade edilmiştir (Pettegrew ve Day, 2015:122).

\section{TÜRKIYY'DE AKILLI TELEFON PIYYASASI}

Türkiye İstatistik Kurumu tarafından 2016 yılında yapılan Hanehalkı Bilişim Teknolojileri Kullanım Araştırmasına göre Türkiye genelinde İnternet bağlanma firsatına sahip hanelerin oranı Nisan ayında \%76,3 olmuştur. Hanelerin 2016 yılı Nisan ayında \%96,9'unda cep telefonu veya akıllı telefon bulunurken, aynı çalışmada kişilerin internet kullanımı amaçlarının \%82,4'ü sosyal medya üzerinde profil oluşturma, mesaj gönderme veya fotoğraf ya da içerik paylaşma, \%74,5 ile video izleme, \%69,5 ile haber, gazete ya da dergi okuma, $\% 65,9$ ile sağlıkla ilgili bilgi arama, \%65,5 ile mal ve hizmetler hakkında bilgi arama ve \%63,7 ile internet üzerinden müzik dinleme olduğu saptanmıştır (TUİK, 2016: 2).

Türkiye ve dünyada akıllı cep telefonu kullanımında hızlı artış olduğu bilinmektedir. Uluslararası bir dijital pazarlama ajansı tarafından yapılan araştırmada dünya nüfusunun yarısından fazlasının en az bir akıllı cep telefonu kullandığı ve dünya genelinde web trafiğinin yarısından fazlasının cep telefonu kaynaklı olduğu ifade edilmiştir (We are social and Hootsuite, 2017). Raporda Türkiye'ye ilişkin istatistiklere de yer verilmiş olup Türkiye'de cep telefonu kullanıcılarının \%75'inin akıllı telefon kullandığı ve kişilerin ortalama günde 3 saatini telefon üzerinden internete bağlanarak sosyal medya platformlarında geçirdiği ifade edilmiştir. Türkiye'nin web trafiği incelendiğinde kişilerin internet girişlerinde 2017 y1lı itibariyle \%61 oranında mobil cep telefonu aracılığıyla \%39'unun kişisel bilgisayarlar aracılığıyla internete bağlandığı ifade edilmiştir. Bu sonuçlar Türkiye'de cep telefonlarının iletişim özelliğinin yanında bilişim özelliklerinin de sıklıkla kullanıldığını göstermektedir.

Çalışmanın bu kısmında Türkiye'nin cep telefonu piyasasını analiz etmek amacıyla cep telefonu dış ticaret verileri elde edilmiştir. Veriler cep telefonunun gümrük tarife istatistik pozisyonu (Gtip kodları) kullanılarak uluslararası ticaret merkezine bağlı trademap veri tabanından 851712000011 kodu kullanılarak elde edilmiştir. 
Tablo 1. Ak1ll telefon ihracat ve ithalat rakamları

\begin{tabular}{|c|c|c|c|c|}
\hline & İthalat & $\begin{array}{c}\text { İthalat } \\
\text { Artış Oranı }\end{array}$ & İhracat & $\begin{array}{c}\text { İhracat Artış } \\
\text { Oranı }\end{array}$ \\
\hline $\mathbf{2 0 0 7}$ & $1,722,948$ & 0 & 8,326 & 0 \\
\hline $\mathbf{2 0 0 8}$ & $1,436,495$ & $-0,16$ & 16,574 & 0,991 \\
\hline $\mathbf{2 0 0 9}$ & $1,071,252$ & $-0,25$ & 10,116 & $-0,390$ \\
\hline $\mathbf{2 0 1 0}$ & $1,302,169$ & 0,21 & 18,802 & 0,859 \\
\hline $\mathbf{2 0 1 1}$ & $1,744,300$ & 0,33 & 18,752 & $-0,003$ \\
\hline $\mathbf{2 0 1 2}$ & $1,716,495$ & $-0,02$ & 29,489 & 0,573 \\
\hline $\mathbf{2 0 1 3}$ & $2,690,106$ & 0,56 & 34,674 & 0,176 \\
\hline $\mathbf{2 0 1 4}$ & $2,996,943$ & 0,11 & 22,521 & $-0,350$ \\
\hline $\mathbf{2 0 1 5}$ & $3,136,597$ & 0,04 & 30,709 & 0,364 \\
\hline $\mathbf{2 0 1 6}$ & $3,058,378$ & $-0,03$ & 69,663 & 1,268 \\
\hline $\mathbf{2 0 1 7}$ & $2,833,942$ & -0.07 & 37,949 & $-0,46$ \\
\hline $\mathbf{2 0 1 8}$ & $1,966,998$ & $-0,30$ & 33,359 & $-0,10$ \\
\hline
\end{tabular}

Kaynak: https://www.trademap.org (Erişim Tarihi: 24.02.2020)

Tablo 1'de 2007 ve 2018 yılları arasında Türkiye'nin dünyadan yaptığı cep telefonu ithalatı, bir önceki yıla göre ithalat artış oranı, cep telefonu ihracatı ve bir önceki yıla göre ihracat artış oranı istatistikleri verilmiştir. İthalat verileri incelendiğinde 2008 yılında gerçekleşen finansal krizi dönemi dışında artış eğilimi dikkat çekmektedir. 2007 yılında 1.7 milyar dolar olan cep telefonu ithalatı on sene sonra 2016 yılında 1.77 kat artmış 3 milyar doları geçmiştir. 2016 yılında dünya ticaret merkezi verilerine göre Türkiye'nin ithalat1 198 milyar dolar olup aynı yılda cep telefonu ithalatının toplam ithalata oranı \%1.5 civarındadır. 20072016 yılları arasında toplam cep telefonu ithalatı 20 milyar doların üstündedir. 


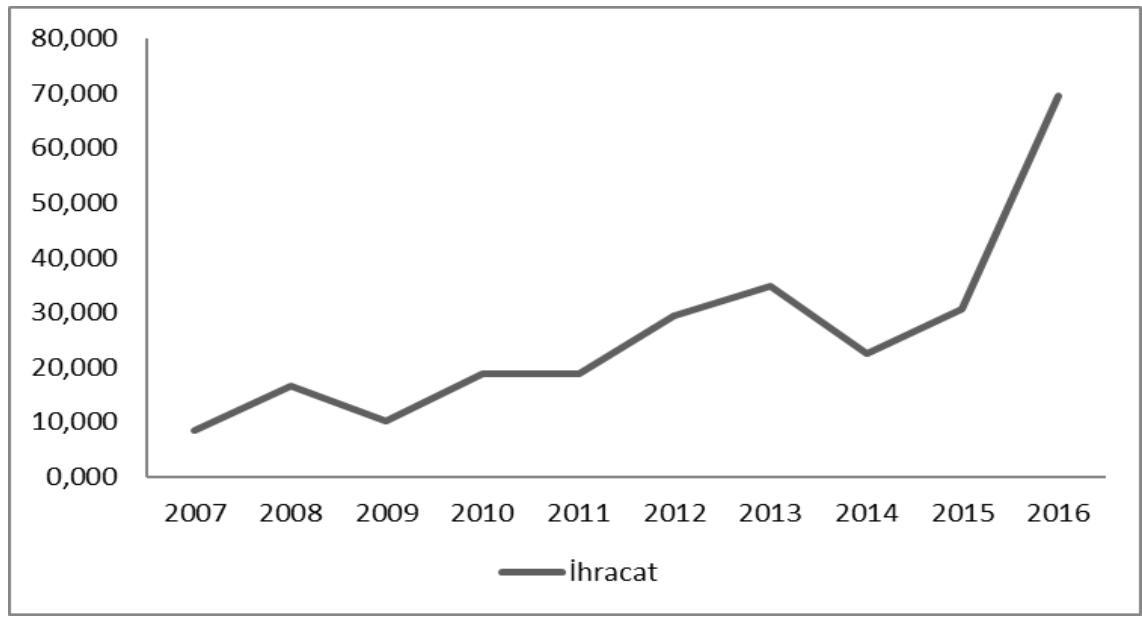

Şekil 2. Cep telefonu ihracatı

Kaynak: Trade Map verileri kullanılarak yazar tarafından hazırlanmıştır.

Son yıllarda Türkiye'de yerli cep telefonu üretiminde de hızlı gelişmeler yaşanmaktadır. Vestel firması Venüs serisi ile Casper ve General Mobile firmaları cep telefonlarını made in Turkey baskısıyla tüketiciye sunmaktadır. 2016 yılı itibariyle cep telefonu piyasasında Vestel firmasının pazar payı \%5 Casper firması \%4 ve General Mobile firması ise pazar payını \%11'e kadar çıkmıştır (Ekonomist, 2016: 1). Ayrıca yukarıdaki şekil 2'de trademap veri tabanı üzerinden elde edilen Türkiye'nin son 10 yılına ait ihracat grafiği verilmiştir. Grafik bir bütün olarak büyüme eğilimine sahipken 2014 yılından sonra eğimin artması dikkat çekicidir. Ayrıca tablo:1 incelendiğinde 2015 ve 2016 y1llarında toplam 100 milyon dolarlık ihracat gerçekleşmiştir.

\section{ARAŞTIRMANIN YÖNTEMI VE SONUÇLAR}

Çalışmada kişilerin lüks cep telefonu taleplerini etkileyen faktörleri belirlemek için İstanbul ilinde yüzyüze görüşmek suretiyle rastgele örneklem metoduyla anket uygulaması yapılmıştır. Yüzyüze yapılmasının nedeni internet ortamında gönderilen anketlere zamanında dönüş olmaması ve örneklemin zayıf kalabilmesi, rastgele yapılmasının nedeni ise anketin güvenilirliğini artırmaktır.

Çalışmanın ana kütlesi İstanbul'da yaşayanlar olup, anket soruları güncel cep telefonu kullanım alışkanlıkları doğrultusunda yazar tarafından hazırlanmıştır. Ankette zaman kısıtı nedeniyle ölçek geliştirme sürecine tabi tutulamamıştır. Anketin İstanbul bölgesinde yapılmasının nedeni bu bölgenin Türkiye içerisinde lüks tüketimin en yüksek olduğu bölge olmasıdır. Örneklem büyüklüğü açısından anketin yüzyüze yapılmasının ve eksik cevaplı anketlerin çok olması nedeniyle ancak 258 kişiye uygulanabilmiştir. 
Ankete cevap veren 258 kişinin \%45'i erken \%55'i kadın, \%24'ü 12-18 yaş aralığında, \%50'si 19-26 yaş aralığın da, \%26'sıda 27 yaşın üstünde kişilerden oluşmaktadır. Ankete cevap verenlerin $\% 7$ si ilkokul, \%31'i lise, \%20 önlisans ve \%40’1 lisans ve \%2 si lisansüstü programlardan mezundur. Ayrıca ankete cevap verenlerin babalarının eğitim seviyesi de sorulmuş olup babaların \%67'si ortaokul-ilkokul, \%21'i lise, \%11 lisans ve önlisans mezunudur.

Anketin ikinci kısmında sorular 5'li likert ölçekte sorulardan oluşurken 1 cevab1 kesinlikle katılmıyorum 5 cevabı kesinlikle katılıyorum şeklinde kodlanmıştır. Çalışma da lüks akıllı cep telefonu olarak 1phone 7 modeli tercih edilmiştir. Çünkü anketin yapıldığı dönemde (2018 yılı) henüz Iphone 8 ve 10(X) tanıtımı yapılmamış olup markanın en üst versiyonu olan Iphone 7 aktif olarak satılmaktayd. Uygulamada kişilere Iphone 7'nin fiyatı biraz uygun olsa (biraz uygun olsa ifadesi günlük ağızda çok kullanıldığı için tercih edilmiştir) satın alma eğilimleri hususunda bir soru sorulmuş olup bu soruya verilen cevaplar bağımlı değişken yapılmıştır. Ankete cevap verenlerin \%44'ü satın alma eğiliminde olacaklarını \%46'sı satın almama eğiliminde olacaklarını \%10’uda karasız bir tavır sergilemişlerdir.

Çalışmanın ilk kısmında yukarıda bahsedilen bazı demografik özelliklerin kişilerin Iphone 7 talebine etkisi araştırmak için Anova testi uygulanmıştır. Bu demografik özelliklerin seçiminde cep telefonu tüketiminde özellikle ülke şartları ve literatür dikkate alınmıştır. Temel hipotezler aşağıdaki gibidir.

H(1):Kişilerin babasının eğitimi ile Iphone 7 talebi arasında istatistiksel olarak anlamlı bir farklılık yoktur.

H(2):Kişilerin kendi ĕ̌itimi ile Iphone 7 talebi arasında istatistiksel olarak anlamlı bir farklılık yoktur.

H(3): Kişilerin yaş aralığ ile Iphone 7 talebi arasında istatistiksel olarak anlamlı bir farklilık yoktur.

H(4): Kişilerin cinsiyeti ile Iphone 7 talebi arasında istatistiksel olarak anlamlı bir farklılık yoktur.

Anova testinin iki varsayımı bulunmaktadır. Varsayımlardan birisi, bağımsız değişkenlerin normal dağılması gerektiğidir. Anova testinin bir diğer varsayımı ise bağımlı 
değişkene ilişkin varyansların birbirine benzer dağılmasıdır (Büyüköztürk, 2007: 47). Tablo 2'de kullanılan bağımlı ve bağımsız değişkenlerin temel istatistik sonuçları verilmiştir.

Tablo 2. Temel istatistik sonuçları

\begin{tabular}{|l|c|c|c|c|c|}
\hline & $\mathbf{N}$ & Ortalama & $\begin{array}{c}\text { Standart } \\
\text { Sapma }\end{array}$ & Skewness & Kurtosis \\
\hline Iphone 7 Satın AIma Eğilimi & 258 & 2,94 & 1,564 &, 054 & $-1,564$ \\
\hline Yaş & 258 & 2,02 &, 706 &,- 022 &,- 979 \\
\hline Cinsiyet & 258 & 1,55 &, 499 &,- 188 & $-1,980$ \\
\hline Ĕgitim & 258 & 2,95 & 1,028 &,- 253 & $-1,181$ \\
\hline Babanın Eğitimi & 258 & 1,52 &, 909 & 1,821 & 2,274 \\
\hline
\end{tabular}

Tablo 2 incelendiğinde basıklık ve çarpıklık değerlerinin $+2,-2$ aralığında olduğu gözükmektedir. $\mathrm{Bu}$ aralık normal dağılım için sorunsuz bir aralık olarak kabul edilmektedir (George ve Mallery, 2010). Ayrıca veri setinin standart sapmaları incelendiğinde Iphone 7 alma eğilimi dışında 1,5 değerinin altında çıkmıştır.

Tablo 3. Varyansların homojenliği testi

\begin{tabular}{|c|c|c|}
\hline Değişkenler & Levene İstatiği & Olasılık Değeri(Sig) \\
\hline Yaş &, 109 &, 897 \\
\hline Cinsiyet & 3897 &, 051 \\
\hline Ĕgitim & 734 &, 570 \\
\hline Babanın Eğitimi & 2763 &, 043 \\
\hline
\end{tabular}

Varyansların homojenliği Levene testi yardımıyla analiz edilmiştir. Babanın eğitim değişkeni dışında 3 değiş̧ken içinde 0,05 anlamlılık düzeyinde varyanslar homojen dağılmıştır (Kalaycı, 2005: 219). Babanın eğitim durumu değişkeni de 0.05 kritik aralığına çok yakın bir değer almıştır.

Tablo 4. Anova test sonuçları

\begin{tabular}{|c|c|c|c|c|}
\hline Gruplar Arası & $\begin{array}{c}\text { F } \\
\text { Değeri }\end{array}$ & $\begin{array}{c}\text { Olasılık } \\
\text { Değeri(sig) }\end{array}$ & $\begin{array}{c}\text { Kareler } \\
\text { Toplamı }\end{array}$ & $\begin{array}{c}\text { Kareler } \\
\text { Ortalaması }\end{array}$ \\
\hline Yaş & 4,261 &, 006 &, 009 &, 009 \\
\hline Cinsiyet &, 004 &, 953 & 30,139 & 10,046 \\
\hline Ĕgitim & 1,096 &, 359 & 10,713 & 2,678 \\
\hline Babanın Ĕğitimi & 3,098 &, 047 & 14,919 & 7,460 \\
\hline
\end{tabular}

$\mathrm{P}<, 05$

Tablo 4'te Anova test sonuçları verilmiştir. Olasılık değerleri incelendiğinde $H(4), H(2)$ hipotezleri kabul edilirken $\mathrm{H}(1)$ ve $\mathrm{H}(3)$ hipotezleri red edilirken kişilerin yaş aralığı ile 
babasının eğitim durumunun Iphone 7 alma eğilimini etkilediğini tespit edilmiştir. Çalışmanın literatür kısmında da ifade edildiği gibi daha çok üniversite öğrencilerinin akıllı telefona eğilimli olmaları bu sonucu açıklayabilmektedir.

Tablo 5. Tukey test sonuçları

\begin{tabular}{|l|c|c|c|}
\hline & $\begin{array}{c}\text { Ortalama } \\
\text { Farkları }\end{array}$ & $\begin{array}{c}\text { Standart } \\
\text { Hata }\end{array}$ & $\begin{array}{c}\text { Olasılık } \\
\text { Değeri }\end{array}$ \\
\hline 12- 18 yaş/ 27 yaş üstü &, 665 &, 274 &, 042 \\
\hline Babanın İlkokul, ortaokulu mezunu/lise mezunu &,- 777 &, 237 &, 007 \\
\hline
\end{tabular}

$\mathrm{P}<, 05$

Anova testinde etkili çıkan iki değişkenin post-hoc testleri Tukey testi yardımıyla yapılmıştır. Sadece istatistiksel olarak anlamlı çıkan sonuçlar verilirken 12-18 yaş aralığı ile 27 yaş ve üzeri yaş aralığına sahip olanların Iphone 7 alma eğilimlerinde farklılaştıkları ayrıca kişinin babasının ilkokul-ortaokul yâda lise mezunu olmasının Iphone 7 alma eğilimini etkilediği tespit edilmiştir.

Çalışmanın bu kısmında Kişilerin lüks akıllı cep telefonu alma eğilimini etkileyen faktörleri ölçmek için çok değişkenli regresyon modeli kurulmuştur. Daha öncede ifade edildiği gibi kişilerin Iphone 7 eğilimi modelde bağımlı değişken olarak kullanılmış olup temel hipotezler aşağıdaki gibidir.

H(5): Iphone fiyatlarını takip etmek ile Iphone 7 satın alma eğilimi arasında istatistiksel olarak anlamlı bir ilişki vardır.

H(6): Markalı ürünlerin internette fiyatlarının uygun olduğu fikri ile Iphone 7 satın alma eğilimi arasında istatistiksel olarak anlamlı bir ilişki vardır.

H(7): Fiyat biraz yüksek olsa bile daha uzun süre kullanma düşüncesiyle markalı ürün tercih etme eğilimiyle Iphone 7 satın alma eğilimi arasında istatistiksel olarak anlamlı bir ilişki vardir. 
Tablo 6. Regresyon analiz sonuçları

\begin{tabular}{|l|c|c|c|c|c|c|}
\hline Bağımsız Değişken & Beta & $\begin{array}{c}\text { Standart } \\
\text { Beta }\end{array}$ & $\begin{array}{c}\text { T } \\
\text { değeri }\end{array}$ & $\begin{array}{c}\text { T } \\
\text { Sig }\end{array}$ & $\begin{array}{c}\text { Standart } \\
\text { Hata }\end{array}$ & VIF \\
\hline Iphone Fiyatlarını Takip Etme &, 641 &, 567 & 11,611 &, 000 &, 055 & 1,064 \\
\hline $\begin{array}{l}\text { Markalı ürünlerin internette fiyatlarının uygun } \\
\text { olduğu fikri }\end{array}$ &, 182 &, 150 & 3,064 &, 002 &, 059 & 1,070 \\
\hline $\begin{array}{l}\text { Fiyat biraz yüksek olsa bile daha uzun süre } \\
\text { kullanma düşüncesiyle markalı ürün tercih etme } \\
\text { eğilimi }\end{array}$ &, 164 &, 139 & 2,769 &, 006 &, 059 & 1,124 \\
\hline
\end{tabular}

$\mathrm{P}<, 05$

Tablo 6'da regresyon analiz sonuçları incelendiğinde bütün bağımsız değişkenler için olasılık değerinin, 0,05'den küçük çıktığı gözükmektedir. Bu katsayıların istatistiksel olarak anlamlı olduğunu ve ilişki olduğunu göstermektedir. 3 bağımsız değişken için beta değerleri pozitif bir değer almıştır. Bu durum üç bağımsız değişkendeki artışın bağımlı değişkeni artırdığını göstermektedir. Standart beta değerleri incelendiğinde en güçlü etkinin Iphone fiyatlarını takip etme olduğu kişilerin Iphone fiyatlarını takipte bir standart sapmalık artışın kişilerin Iphone 7 alma eğilimlerini 0,64 standart sapma kadar artırdığını göstermektedir. Ayrıca kişilerin markalı ürünlerin internette fiyatlarının uygun olduğu fikrindeki artış ve fiyat biraz yüksek olsa bile daha uzun süre kullanma düşüncesiyle markalı ürün tercih etme eğilimindeki artış Iphone 7 satın alma eğilimini artırmıştır.

Tablo 7. Tanı testi ve model sonuçları

\begin{tabular}{|c|c|c|c|c|c|}
\hline $\begin{array}{c}\text { F } \\
\text { Değeri }\end{array}$ & $\begin{array}{c}\text { F olasılık } \\
\text { Değeri }\end{array}$ & $\begin{array}{c}\text { Durbin } \\
\text { Watsın }\end{array}$ & Re-kare & $\begin{array}{c}\text { Artıkların } \\
\text { Skewness }\end{array}$ & $\begin{array}{c}\text { Artıkların } \\
\text { Kurtosis }\end{array}$ \\
\hline 63,913 &, 000 & 1,975 &, 430 &, 233 &, 454 \\
\hline
\end{tabular}

$$
\mathrm{P}<, 05
$$

Tablo 7'de kurulan modele ilişkin tanı testleri ve model sonuçları verilmiştir. Kurulan modelin bir bütün olarak anlamlılığını test eden F testi olasılık değeri 0,05' den küçük çıkmıştır. $\mathrm{Bu}$ değer modelimizin bir bütün olarak anlamlı olduğunu göstermektedir. Doğrusal regresyon modellerinin varsayımlarından birisi otokorelasyon olarak tabir edilen hata terimlerinin birbirini etkilememesi gerekliliğidir. Oto korelasyon testi için Durbin Watsın değeri tahmin edilmiş olup bu değerin 1,5-2,5 aralığında olması oto korelasyon sorununun olmadığını göstermektedir (Kalayc1, 2005: 267). 
Regresyon modellerinin bir diğer varsayımı bağımsız değişkelerin birbirini etkilememesi yani çoklu doğrusal bağlantı sorunu olmaması gerekliliğidir. Tablo 6'da VIF değerleri incelendiğinde 3 bağımsız değişken içinde 1'e çok yakın değerlerdir. Bu durum bağımsız değişkenler arasında ilişkinin çok zayıf olduğunu göstermektedir (Kalaycı, 2005: 267). Kurulan modelin artıklarının basıklık ve çarpıklık değerleri de +- 1,5 aralığındadır. $\mathrm{Bu}$ sonuç model artıklarının normale yakın dağıldığını göstermektedir (Tabachnick ve Fidell, 2013).

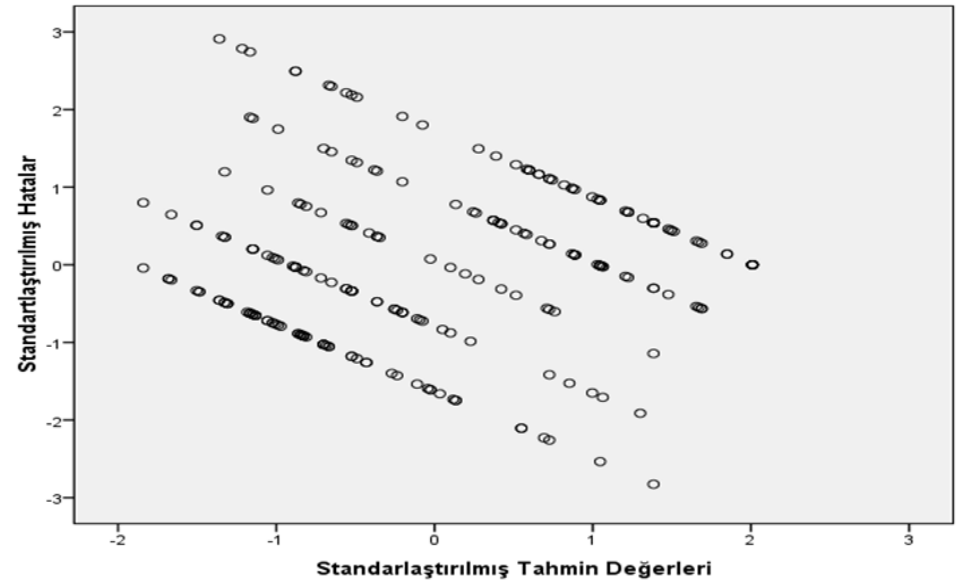

Şekil 3. Değişen varyans diyagramı

$\mathrm{Bu}$ bölümde son olarak doğrusal regresyon modellerindeki değişmeyen varyans varsayımı test edilecektir. Yukarıda Şekil 2'de hataların serpilme diyagramı verilmiştir. Diyagram incelendiğinde ufakta olsa aşağı doğru bir eğim vardır. Bu eğim gözlemler arttıkça varyansların az bir ölçüde azaldığını göstermektedir. Fakat diyagram da çok sert bir azalma ya da artma eğiliminin olmaması kısmen varyansların benzeştiğini göstermektedir.

\section{SONUÇ}

Son yıllarda Cep telefonu kişilerin hayatında bağlılık seviyesinde kullandıkları bir ürün haline gelmiştir. Cep telefonları sağladığı fayda itibariyle hayatı kolaylaştırırken hızlı internet erişimi sağlaması ve geniş dokunmatik ekranlarıyla kişisel bilgisayarların yerini almakta ve cep telefonu yerine akıllı telefon olarak ifade edilmektedir. Sürekli yenilenen ve hızlı değişen bir ürün olması sebebiyle cep telefonları periyodik olarak değiştirilen ve fiyatı artan bir üründür.

Akıllı telefon bağımlılı̆̆ının psikolojik ve fizyolojik sağlık açısından olumsuz etkileri konunun uzmanları tarafından araştırılırken son yıllarda artan lüks cep telefonlan tüketiminin de hem ithalatı artırdığ 1 hem de ev ekonomilerine zarar verdiği bilinmektedir. Akıllı telefon 


\section{Tunç, H.}

talebinde üniversite öğrencilerinin ön plana çıkması bu sektörün orta gelir seviyesinden büyük pay aldığını göstermektedir.

Son dönemde başta devlet olmak üzere bütün iktisadi karar vericiler her alanda yerli üretimin gelişmesi için yoğun çaba harcamaktadır. Akıllı telefon sektöründe de 3 farklı firmanın yerli cep telefonu üretimine başlaması ve Türkiye' nin 2016 yılında 70 milyon dolar cep telefonu ihracatı gerçekleştirmesi bu çabanın akıllı telefon sektöründe karşılık bulduğunun göstergesidir.

Bu çalışmada akıllı lüks cep telefonu olarak Iphone 7 cep telefonu talebini etkileyen faktörler incelenmeye çalışılmıştır. Öncelikle kişilerin yaş aralığı ve babalarının eğitim seviyesi Iphone 7 talebini etkilemiştir. Bu durum özellikle genç nüfusun lüks mallara olan yoğun talebini ve bir ebeveyn rolüyle babanın lüks tüketimde kontrol odağı olduğunu göstermektedir.

Ayrıca Iphone fiyatlarını takip etmenin, internette markalı bazı ürünlerin ucuz olduğunu düşüncesinin ve fiyat biraz yüksek olsa bile daha uzun süre kullanma düşüncesiyle markalı ürün tercih etme eğiliminin, kişilerin Iphone 7 cep telefonu alma eğilimleri ile pozitif yönlü bir ilişkiye sahip olduğu tespit edilmiştir. Kişilerin lüks tüketiminde gelir kadar ilgili malların fiyatı ve bu mallara ulaşmanın kolaylığıda talebi etkilemiştir.

Literatür incelendiğinde Cep Telefonu ile alakalı çalışmalar daha çok öğrenciler üzerinde yapılırken bu çalışmada İstanbul bölgesinde ve kişiler üzerinde yapılması açısından farklılık oluşmuştur. Ayrıca lüks tüketim üzeründe aynı markanın masaüstü ya da dizüstü bilgisayarlarının talebi konusunda da çalışmalar yapılabilir. Çünkü bu ürünlerinde rakiplerinden farklı oldukları göze çarpmaktadır.

\section{REFERENCES / KAYNAKLAR}

Bomhold, C. (2013). Educational use of smart phone technology: A survey of mobile phone application use by undergraduate university students, program. Home Browse Journals \& Books, 47(4), 424-436.

Büyüköztürk, Ş. (2007). Sosyal bilimler için veri analizi el kitabı (7. Baskı). Ankara: Pegem Yayıncılık.

Ekonomist. (2017). Akıllı telefonda yerli atağa geçti. Erişim Tarihi: 18.02.2018, Http://Www.Ekonomist.Com.Tr/Teknoloji/Akilli-Telefonda-Yerliler-Ataga-Gecti.Html

George, D. \& Mallery, M. (2010). SPSS for windows step by step: A simple guide and reference 17.0 update. Boston: Pearson.

Gökaliler, E., Aybar, A. S. \& Gülay G. S. (2011). Bir statü tüketimi göstergesi olarak Iphone markalı akıllı telefon algısı: Üniversite öğrencileri üzerine bir araştırma. Selçuk İletişim, 7(1), 36-48. 
Gülmez, M. (2005). Üniversite öğrencilerinin cep telefonu satın alma ve kullanımını etkileyen faktörler: Sivas Cumhuriyet Üniversitesi ile Tokat Gaziosmanpaşa Üniversitelerinde bir uygulama. Erciyes Üniversitesi İktisadi ve İdari Bilimler Fakültesi Dergisi, 24, 37-62.

Hsiao, M. H. \& Chen, C. L. (2015). Smart phone demand: An empirical study on the relationships between phone handset, internet access and mobile services. Telematics and Informatics, 32(1), 158-168.

Kalaycı, Ş. (2005). SPSS uygulamalı çok değişkenli istatistik teknikleri (1. Baskl). Ankara: Asil Yayın Dağıtım.

Karaaslan, İ. A. \& Budak, L. (2012). Üniversite öğrencilerinin cep telefonu özelliklerini kullanımlarının ve gündelik iletişimlerine etkisinin araştırılması. Journal of Yasar University, 26(7), 4548-4525.

Kuyucu, M. (2017). Gençlerde akıllı telefon kullanımı ve akıllı telefon bağımlılığı sorunsalı: “Akıllı Telefon(Kolik)" üniversite gençliği. Global Media Journal TR Edition, 7(14), 328-359.

Özaşçılar, M. (2012). Genç bireylerin cep telefonu kullanımı ve bireysel güvenlik: Üniversite öğrencilerinin cep telefonunu bireysel güvenlik amaçlı kullanımları. Sosyoloji Araştırmaları Dergisi, 15(1), 42-74.

Pettegrew, L. S. \& Day, C. (2015). Smart phones and mediated relationships: The Changing face of relational communication. Journal Review of Communication, 15(2), 122-139.

Robert, J. A., Pullig, C. \& Manolis, C. (2015). I need my smartphone: A hierarchical model of personality and cell-phone addiction. Personality and Individual Differences,79, 13-19.

Sargent, T. J. \& Wallace, N. (1976). Rational expectations and the theory of economic policy. Journal of Monetary Economics, 2(2), 169-183.

Suki, N. M. (2013). Students' dependence on smart phones: The influence of social needs, social influences and convenience. Campus-Wide Information Systems, 30(2), 124-134. https://doi.org/10.1108/10650741311306309

Şahin, A. (2005). Remm modeli çerçevesinde bireylerin iktisadi davranışlarının analizi. Elektronik Sosyal Bilimler Dergisi, 3(12), 191-199.

Tabachnick, B. G. \& Fidell, L. S. (2013). Using Multivariate Statistics (Sixth ed.). Boston: Pearson.

TUİK (2016). Hanehalkı bilişim teknolojileri kullanım araştırması (Sayı: 21779). Ankara.

Türkay, O. (1986). Mikro iktisat teorisi. Ankara Üniversitesi Siyasal Bilgiler Fakültesi Yayınları, 551, Ankara.

Tüzüntürk, S. (2017). Uyum analizi kullanarak y kuşağı akıllı telefon kullanıcılarının tüketici davranışlarının anlaşılması: Bursa örneği. Marmara Üniversitesi İktisadi ve İdari Bilimler Dergisi, 39(1), 257-280.

Uzgören, E., Şengür, M. \& Yiğit, Ü. (2013). Üniversite öğrencilerinin cep telefonu talebinde israfa yönelik davranışlarının analizi dumlupınar üniversitesi öğrencilerine yönelik bir uygulama. Süleyman Demirel Üniversitesi Íktisadi ve İdari Bilimler Fakültesi Dergisi, 18(1), 29-44.

Ünsal, E. M. (1998). Mikro iktisat. Ankara: Kutsan Ofset Matbaacılık.

Varian, H. R. (2010). Intermediate microeconomics: A modern approach (Eighth Edition). New York: W. W. Norton \& Company.

Watsin, C., Mccarthy, J. \& Rowley, J. (2013). Consumer attitudes towards mobile marketing in the smart phone era. International Journal of Information Management, 33(5), 840-849.

We Are Social and Hootsuite. (2017). Erişim Tarihi: 18.02.2018, https://wearesocial.com/special-reports/digitalin-2017-global-overview

Yaşa, E. \& Bozyiğit S. (2012). Y kuşağı tüketicilerinin cep telefonu ve gsm operatörleri tercihi: Mersin ilindeki üniversite öğrencilerinin tercihlerini belirlemeye yönelik pilot bir araştırma. Cag University Journal of Social Sciences, 9(1), 29-47. 